\title{
Photosynthesis, yield and raw material quality of sugarcane injured by multiple pests
}

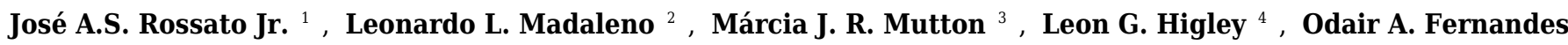
Corresp. 3

${ }^{1}$ Faculdade Dr.Francisco Maeda - Fafram, Ituverava, SP, Brazil

2 Faculdade de Tecnologia - FATEC, Jaboticabal, Sao Paulo, Brazil

3 Universidade Estadual Paulista (Unesp), Faculdade de Ciências Agrárias e Veterinárias, Jaboticabal, SP, Brazil

4 University of Nebraska - Lincoln, School of Natural Resources, Lincoln, Nebraska, United States

Corresponding Author: Odair A. Fernandes

Email address: odair.fernandes@unesp.br

Understanding sugarcane (Saccharum spp.) response to multiple pest injury, sugarcane borer (Diatraea saccharalis) and spittlebug (Mahanarva fimbriolata), is essential to make better management decisions. Moreover, the consequences of both pests on the sugarcane raw material quality have not yet been studied. A field experiment was performed in São Paulo State, Brazil, where sugarcane plants were exposed to pests individually or in combination. Plots consisted of a 2-m long row of caged sugarcane plants. Photosynthesis was measured once every 3 months (seasonal measurement). Yield and sugar production were assessed. The measured photosynthesis rate was negatively affected by both borer and spittlebug infestations. Photosynthesis reduction was similar on plants infested by both pests as well as by spittlebug individual infestation. Plants under spittlebug infestation resulted in yield losses and represented $17.6 \%$ (individual infestation) and $15.5 \%$ (multiple infestations). The sucrose content and the sucrose yield per area were reduced when plants were infested by multiple pests or spittlebug. 
1 Photosynthesis, yield and raw material quality of sugarcane injured by multiple pests

2

3

4 José A. S. Rossato Jr. ${ }^{1}$, Leonardo L. Madaleno², Márcia J. R. Mutton ${ }^{3}$, Leon G. Higley ${ }^{4}$ and

8 Faculdade Dr. Francisco Maeda - FAFRAM, Ituverava, 14500-000, São Paulo, Brazil

$9 \quad{ }^{2}$ Faculdade de Tecnologia de Jaboticabal Nilo De Stefani - FATEC, Jaboticabal, 14883-130,

São Paulo, Brazil

11

${ }^{3}$ Universidade Estadual Paulista (Unesp), Faculdade de Ciências Agrárias e Veterinárias,

12 Jaboticabal, 14884-900, São Paulo, Brazil

${ }^{4}$ University of Nebraska - UNL, School of Natural Resources, Lincoln, 68503-0816, Nebraska,

14 USA

20 *corresponding author

21 Odair Aparecido Fernandes

22 Universidade Estadual Paulista (Unesp), Faculdade de Ciências Agrárias e Veterinárias,

23 Jaboticabal, 14884-900, São Paulo, Brazil 
24 Phone: + 551632097304

25 E-mail: odair.fernandes@unesp.br

\section{Abstract}

27 Understanding sugarcane (Saccharum spp.) response to multiple pest injury, sugarcane borer (Diatraea saccharalis) and spittlebug (Mahanarva fimbriolata), is essential to make better management decisions. Moreover, the consequences of both pests on the sugarcane raw material quality have not yet been studied. A field experiment was performed in São Paulo State, Brazil, where sugarcane plants were exposed to pests individually or in combination. Plots consisted of

32 a 2-m long row of caged sugarcane plants. Photosynthesis was measured once every 3 months

33 (seasonal measurement). Yield and sugar production were assessed. The measured

34 photosynthesis rate was negatively affected by both borer and spittlebug infestations.

35 Photosynthesis reduction was similar on plants infested by both pests as well as by spittlebug 36 individual infestation. Plants under spittlebug infestation resulted in yield losses and represented $3717.6 \%$ (individual infestation) and $15.5 \%$ (multiple infestations). The sucrose content and the sucrose yield per area were reduced when plants were infested by multiple pests or spittlebug. 


\section{Introduction} one of the most important pests of sugarcane, Saccharum spp., and maize, Zea mays L., occurs in several countries of the Americas, and is commonly found in all sugarcane producing areas in those countries (Dinardo-Miranda, 2008; White et al., 2008). However, sugarcane plants are also injured by several other insect pests that may cause economic losses (Guagliumi, 1973).

During the 1990's in Brazil, the use of fire to burn sugarcane fields for manual harvesting was replaced by mechanical harvesting. This new harvesting system allows a large amount of shredded sugarcane leaves and tips to be kept on the soil surface causing environmental changes in sugarcane habitat. Abiotic modifications such as higher soil moisture and lower solar irradiation on the protected surface of the soil have favored outbreaks of the native spittlebug, Mahanarva fimbriolata (Stål, 1854) (Hemiptera: Cercopidae), and this insect has become an important pest of sugarcane in Brazil (Mendonça, Barbosa \& Marques, 1996; Dinardo-Miranda,

63 Garcia \& Coelho, 2001; Garcia et al., 2011). The spittlebug is particularly important during the wet season when nymphs and adults occur, whereas the sugarcane borer can damage the crop at any time of the year.

67 to physiologic processes such as respiration, transpiration, and photosynthesis (Welter, 1989; Higley, Browde \& Higley, 1993). Photosynthesis influences plant biomass accumulation, and

69 plants exhibiting high photosynthetic rates may result in higher yields (Haile, 2001). In addition 
to yield reductions, pest injury can also negatively affect yield quality, and reductions in quality have been reported for spittlebug-infested plants (Madaleno et al., 2008; White et al., 2008; Ravaneli et al., 2011).

Because sugarcane production in Brazil now routinely faces simultaneous injury by two important insect pests, characterizing sugarcane responses to these pests individually and in combination is essential for proper pest management. Of particular concern is the recognition that plant response to combined stressors may be greater than the sum of plant response to each pest individually (Peterson \& Higley, 2001). Despite the importance of the two sugarcane pests and their simultaneous occurrence during part of the growing season, sugarcane response to the injury of these pests combined has not been examined. Moreover, knowledge of plant responses to simultaneous injury by pests can be an important tool to improve current decision-making thresholds, because the occurrence of pests in field may not be isolated in time.

In most agricultural plants, yield (defined by humans as seeds, leaves, tubers, or stems, for example) is indirectly related to primary metabolism. However, in sugarcane yield can be defined as sugar (or a direct product of sugar, like ethanol), and sugar is a direct product of photosynthesis. Consequently, changes in photosynthesis from pest injury should be directly related to yield loss. Thus, our objective in this study was to evaluate the impact of these two pests, individually and in combination, on photosynthesis and its direct impact on yield and yield quality of sugarcane.

\section{Material and Methods}

The experiment was carried out in a commercial sugarcane area $\left(21^{\circ} 19^{\prime} \mathrm{S}\right.$ and $\left.48^{\circ} 06^{\prime} \mathrm{W}\right)$, Ribeirão Preto region, São Paulo State, Brazil in 2008-2009 The sugarcane variety selected was 
93 SP80-3280 (4th ratoon), which is considered susceptible to both spittlebug and sugarcane borer

94 (Dinardo-Miranda, 2003). Planting density was 12 stalks/row-m.

Typically, studies on photosynthetic responses of plants to insect injury are conducted

96 within a single season (at times of peak photosynthetic activity), while studies on yield losses

97 from insect injury are conducted over multiple seasons (to accommodate environmental

98 variation, particularly, water availability). Because our focus here is on photosynthesis and

99 photosynthate (sugar) accumulation, our experiment was conducted in a single growing season.

100 Additionally, we used this study to establish whether or not multiple pest interactions occurred,

101 which would require more detailed examination. Elsewhere (Rossato, 2012), relationships

102 between insect injury and yield loss are reported from multi-seasonal studies arising from the

103 research reported here.

104 The experimental design was a randomized complete block treatment arrangement with

105 four replications. Treatments were blocked by row. The experimental unit was a 2 x 2 m cage

106 over a row. Experimental units were randomly assigned within a block. Although uncaged

107 controls (a designated $2 \times 2 \mathrm{~m}$ area in a row) were established, these could not be used for

108 determining potential cage effects, because all uncaged controls had high infestations rates of

109 sugarcane borers. Treatments included caged sugarcane plants a) infested by spittlebug alone; b)

110 infested by sugarcane borer alone (high infestation); c) infested by spittlebug + sugarcane borer;

111 and d) plants without insects (control). Consequently, there were 3 insect treatments and 1

112 control treatment for a total of 16 experimental units ( 4 treatments $\mathrm{x} 4$ blocks). Each

113 experimental unit consisted of 2-m row of sugarcane plants, protected by a metallic cage covered

114 with anti-aphid screen $(1 \mathrm{x} 1 \mathrm{~mm})$ to avoid insect movement into or out of the experimental units. 
115 The cages were placed over plants at the 1 to 2 internode plant growth stage, which is when

116 stalks are naturally infested by sugarcane borer but are without spittlebug infestation.

Although our description of the experimental design implies conventional treatment

118

119

120

121

122

123

124

125

126

127

128

129

130

131

132

133

134

135

136

137

assignments, this was not the case for the sugarcane borer treatments. Our original plan was to artificially infest cages with sugarcane borers; however, plants were infested before exclusion cages could be used. Consequently, all treatments (with and without sugarcane borers) had to be established by inspecting plants for evidence of infestation. Establishing treatments in this way seems to violate the assumption of random treatment assignment.

The principle of random treatment assignment is used to avoid potential confounding with treatment effects. In other words, the only factor influencing an experimental unit should be the treatment (or treatment and block effect in blocked designs). Our choice of experimental units is within a sugarcane planting in which plants have the same genetics and are grown under uniform agronomic conditions. While location effects on experimental units were possible, these were accommodated through blocking. Consequently, the one potential confounding factor in assigning treatments based on pre-existing infestations, is whether or not the infestations themselves were random or non-random. Studies on sugarcane borer spatial variability in sugarcane have established that infestations have an aggregated distribution, with areas of higher infestation density randomly distributed through a field (Anjos et al., 2011). Given this understanding of sugarcane borer biology, we believe the use of pre-existing infestation sites for treatment assignment is consistent with the notion of random treatment assignment, albeit with the sugarcane borers doing the randomization rather than the experimenters!

A final point on sugarcane borer treatments is that because infestations have a random distribution, within a group of plants (i.e., within an experimental unit), it is possible to have 
138 high and low levels of infestation among and within plants. Infestation levels of sugarcane borers

139 are determined destructively by splitting stalks, counting sugarcane borer tunnels, and measuring

140 tunnel lengths. Because this approach was not useful for assigning treatments, we used visual

141 inspections for frass (larval feces) and entry holes as indicators. For sugarcane borer-free

142 experimental units we chose plants without frass or entry holes. For sugarcane borer-infested

143 experimental units we chose plants subjectively with high and low levels of infestation

144 indicators. For the sugarcane borer plus spittlebug treatment we identified (again subjectively)

145 high infestation levels of sugarcane borers. Differences in actual sugarcane borer infestation

146 levels were determined at the end of the experiment by splitting stalks and measuring tunneling.

147 Spittlebugs nymphs were used to artificially infest treatments. Nymphs hatched from

148 diapausing eggs and collected from the field. After infestation, spittlebug nymphs were

149 monitored on every stalk at 2 to 3-day intervals and counted. Nymphs were removed from or

150 added to the cages to keep similar infestations in the spittlebug-infested plots. The spittlebug

151 infestation density was expressed as daily infestation (nymph/m/day) as suggested by Madaleno

152 et al. (2008).

153 Photosynthetic rates of sugarcane plants were measured on three plants in each plot. A

154 portable photosynthetic system (Li-Cor, Model LI-6400) was used in each of the seasons: in

155 February (121 days after plant emergence), April (170 days after plant emergence), June (254

156 days after plant emergence), and September (346 days after plant emergence), which

157 characterized summer, fall, winter, and spring, respectively. Measurements were made at an

158 average (ambient) $\mathrm{CO}_{2}$ concentration of $409 \mathrm{ppm}$, average light intensity of $900 \mu \mathrm{E}$ PAR

159 (photosynthetically active radiation) from LED blue-red light source, and average leaf 
160 temperature of $25.3^{\circ} \mathrm{C}$. All photosynthetic measurements were made until the $\mathrm{CV}$ for 161 photosynthesis was less than $3 \%$.

162 During harvest, all senescent leaves were stripped out and all stalks were cut manually

163 from each plot. Length and diameter of each stalk was measured at harvest (348 days after plant

164 emergence). The diameter of each stalk was measured at the middle of the lower most, middle,

165 and upper most internodes using a handheld pachymeter. Stalk yield was obtained using the

166 formula: [(diameter ${ }^{2 *} 15 *$ height*0.007854)/1.5], as described by Landell \& Bressiane (2008).

167 The total internodes were counted. Stalks were longitudinally split to evaluate the internodes

168 injured by sugarcane borer and to determine the Infestation Intensity (II) by dividing the number

169 of borer-damaged internodes by the total number of internodes.

All stalks within a plot were shredded and homogenized to extract the sugarcane juice by

171 a hydraulic press (Tanimoto, 1964). Immediately after extraction, the level of soluble solids

172 (Brix) and the apparent sucrose content (Pol) were determined using methods proposed by

173 Schneider (1979). Phenolic compounds were estimated as proposed by Folin \& Ciocalteu (1927).

174 The sucrose yield per area was calculated using the sucrose content (Pol) and the stalk yield.

Data were analyzed with SAS (SAS Institute, Cary, NC), and treatment effects were

176 determined by repeated measures analysis of variance (GLM). For means comparisons, we used

177 an unprotected least significant difference (LSD) with $(\mathrm{P} \leq 0.05)$. We chose the unprotected LSD

178 at $\mathrm{P}>0.05$ in evaluating differences among means for three reasons. First, our core interest is in

179 identifying differences of insect treatments from the control, and even in a non-significant

180 ANOVA the control could be significantly different from some insect treatments. Second,

181 because we have few treatments the issue of generating false significance is reduced. And third,

182 we wanted to use a liberal comparison so any potential biological differences among treatments 
183 would be identified (or stated another way, we chose to reduce alpha error at the expense of 184 increasing beta error).

185 Graphic presentations of photosynthesis-yield relationships and all regressions were 186 developed with Prism 6.01 software (GraphPad Software, Inc., La Jolla, CA,

187 http://www.graphpad.com/scientific-software/prism/). Details on methods used for evaluating fit 188 of regression models are available in GraphPad documentation (GraphPad Curve Fitting Guide at 189 http://www.graphpad.com/guides/prism/6/curve-fitting/index.htm).

\section{Results and Discussion}

The mean infestation of sugarcane borer was $15.8 \%$ which is considered a high sugarcane

193

194

196

197

198

199

200

201

202

203

204 borer infestation. In the spittlebug treatment, the mean number of nymphs was 3.07

nymphs/m/day. In the treatment with both pests combined, the infestation intensity of sugarcane borer was $13.63 \%$ and 2.95 nymphs/m/day for spittlebug, which were similar to the infestations observed in sugarcane borer and spittlebug treatments, respectively. The control (represented by non-infested caged plants) was not infested by the pests.

Sugarcane plants had the highest average photosynthetic rates in the fall (February) with photosynthetic rates in other seasons approximately half of those in the fall (Fig. 1, control treatments). Abiotic factors such temperature, net radiation, and especially rainfall (Fig. 2), are most favorable to plant development during the fall and likely to account for these photosynthetic rate differences (Taiz \& Zeiger, 2006).

Reductions in photosynthesis were noted from insect injury, but reductions varied by insect and by season. Generally, reductions were observed depending on the stressor on the 
205 plants. Sugarcane plants infested with spittlebugs (alone or combined with borer) had lower

206 photosynthetic rates. Therefore, spittlebug injury reduced photosynthesis.

207 During the period of spittlebug infestation (summer), sugarcane plants showed significant

208 photosynthesis reduction (Fig. 1, Table 1). However, there were no differences between plants

209 under spittlebug infestation and combined infestation of spittlebug and borer, even though it is

210 known that galleries caused by the sugarcane borers can reduce water flow within the plants.

211 This result suggests that the spittlebug injury is worse than borer injury for sugarcane plants.

212 Probably, this impact is related to the long period of feeding by nymphs on the roots. Damage

213 caused by sucking insects may vary considerably depending on the time length of feeding

214 (Reddall et al., 2004; Gomez et al., 2006). Spittlebug nymphs may interrupt the phloem vessels

215 to the roots causing root death (Garcia, Botelho \& Parra, 2006). Also, sucking insects, in general,

216 may remove plant tissue affecting physiological processes, release saliva that is toxic to the

217 plants, and cause tissue necrosis (Fewkes, 1969; Haile, 2001). Nevertheless, when the spittlebug

218 infestation ended in April photosynthetic rate differences were no longer observed.

Reductions in photosynthesis from sugarcane borer were statistically significant only in

220 April. Injury from sugarcane borer is usually greater (longer galleries in the stalk) in the fall than

221 summer (Macedo \& Botelho, 1988), and this may have negatively influenced the physiological

222 processes during this season. Comparing these two seasons, plants with sugarcane borer

223 infestation had showed $63 \%$ (fall) and $56.8 \%$ (summer) photosynthetic reductions whereas non-

224 infested plants showed 43.9\%. Considering that in April the plants were not under optimal

225 abiotic factors (Fig. 2), these data suggest that the difference between photosynthetic rates

226 between non-infested plants and plants under sugarcane borer infestation represents the negative

227 impact of the borer on the plants. The galleries in the stalks may promote similar stress in the 
228 plant as well as drought conditions. Therefore, plants under both abiotic and biotic stressors may

229 have a reduction in nutrients and water flow to leaves (Culy, 2001) and result in a decrease of

230 accumulated biomass (Vaadia, 1985).

231 The effect of photosynthetic rate reduction was reflected on yield at harvest. Plants with

232 spittlebug infestation (individually or combined) showed thinner stalks, and some plants

233 completely dried. Similar results were also reported by Dinardo-Miranda (2003). In this study

234 the diameter and length of stalks were significantly affected when spittlebug was present. This

235 impact in the stalks was caused by the spittlebug nymphs whose feeding injures the roots

236 affecting phloem and xylem flow of water and nutrients, such as nitrogen, phosphorus,

237 potassium, calcium, and glucose (Garcia, Botelho \& Parra, 2006; Dinardo-Miranda, 2008).

238 On the other hand, the diameter of the stalk was not affected by sugarcane borer

239 infestation (Table 1). The infestation intensity was not sufficient to cause any stalk diameter

240 reduction, despite photosynthetic rate reduction observed in April. Diameter and length

241 reductions were enough to cause sugarcane yield losses. Plants infested by spittlebug (alone or

242 combined) were affected negatively for yield losses. Compared to the uninfested plants, stalk

243 yield reduction was 17.6 and $15.5 \%$ under spittlebug individually or spittlebug combined with

244 borer, respectively.

245 According to White et al. (2008), stalk yield losses are positively correlated to borer

246 infestation intensity. However, despite the infestation intensity observed (15.8\%), there was no

247 significant stalk yield reduction. It is possible that some sugarcane varieties may have

248 mechanisms to prevent yield losses even under such an infestation intensity of sugarcane borer.

249 Moreover, the current methodology to estimate injury based on infestation intensities may not

250 predict the actual injury caused by borer in the stalk. Therefore, studies involving the volume of 
251 gallery (length and diameter of the tunnels) made by borers may better represent the infestation

252 ( injury) instead of using bored internodes as an infestation intensity parameter because the

253 severity of injury is partially assessed.

254 There was no difference in the levels of soluble solids in the raw material obtained from

255 plants infested with borer and/or spittlebug. Similar results were observed on plants with

256 spittlebug infestation by Garcia et al. (2010) and Ravaneli et al. (2011).

257 The sucrose yield per area was negatively affected by spittlebug injury, decreasing 15.1

258 and $16.6 \%$, individually or combined with borers, respectively. Regardless of the infestation

259 level of sugarcane borer, there was no significant difference in sucrose yield per area. Thus, these

260 results confirmed that spittlebug injury impact (alone or combined) is worse than borer injury for

261 sucrose yield per area, which is most likely influenced by the stalk reduction.

262

Typically, borer infestations are associated with opportunistic fungi Fusarium

263

264

265

266

267

268

269

270

271

272

273

moliniforme and Colletotrichum falcatum infections. These pathogens enter the galleries and induce the production of metabolite inhibitors and lead to sucrose inversion (Ingram, 1946;

Stupiello, 2010). However, the amount of phenolic compounds was not affected by these fungi, even with pest infestation (Table 1). Sugarcane plants exposed to greater pest infestations may increase the amount of these phenolic compounds which affect quantitatively and qualitatively both sugar and ethanol productions (Ravaneli et al., 2011). In contrast to the results obtained by Garcia et al. (2010) and Ravaneli et al. (2011), the pest infestation was probably lower in our study. Moreover, sugarcane plant produces phenolic compounds naturally and the amount produced is also affected by the plant age and variety (Simioni et al., 2006).

In addition to examining individual treatments, we were interested in potential changes between parameters, particularly between photosynthesis and yield. Although total 
274 photosynthesis clearly relates to yield capacity, efforts to directly relate measures of leaf

275 photosynthesis to final yield have not been very successful (Long et al., 2006) largely because of

276 the many factors (environmental and genetic) that influence this relationship. In looking at insect

277 injury to sugarcane, our hope was that photosynthesis and sugar accumulation would offer a

278 more direct relationship than carbon accumulation and photosynthesis in other plant systems.

279 We used regressions and graphs to illustrate photosynthesis and yield (Fig. 3, Table 2).

280 Figure 3A shows a simple linear regression of yield (sucrose or total stalk wet weight) versus

281 photosynthesis, with data points representing the average by treatment. Our intent with this

282 regression was not to produce a realistic model of the photosynthesis-yield relationship, but

283 rather to see if photosynthesis and yield showed a positive association, independent of other

284 treatment effects. As expected the patterns for sucrose and total stalk weights are similar, but the

285 pattern of increasing yield with increasing mean leaf photosynthesis is not. The points at a mean

286 photosynthetic rate of ca. 9.3 are noticeable lower than expected, and these points are from the

287 sugarcane borer + spittlebug treatment. Figures 3A and 3B use the same data points in non-linear

288 regressions of a Michaelis-Menten equation to offer a more realistic description of relationship

289 between mean photosynthesis and yield. Although Figs. 3A and 3B present curves showing

290 increasing photosynthesis leading to increasing yield (asymptotically), it is noteworthy that

291 excluding the stalk-borer + spittlebug treatment substantially reduces the confidence intervals

292 (Fig. 3B).

The physiological implications of injury from the combination of stalk-borer + spittlebug

294

295

296

are more evident when we look at data by month (i.e.; season), rather than as an average across

months (Fig. 4, Table 2). In February (Fig, 4A), the combined treatment has the lowest

photosynthetic rates (ca. 13.8) of any treatment. However, in April (Fig. 4B), June (Fig. 4C), and 
297 September (Fig. 4D) the combined insect treatment has among the highest photosynthetic rates

298 despite having the lowest associated yields. Consequently, data from April, June, and September

299 for the combined insect treatment is both in contrast to theoretical expectations for

300 photosynthesis and yield and in contrast to relationships seen in other treatments.

301 Theoretically, the potential interaction between pests can involve two mechanisms: (1)

302 stress incidence interactions, where the occurrence of one stressor increases or decreases the

303 incidence of a different stressor, and (2) stress response interactions, where the occurrence of

304 multiple stressors "indicate that physiological processes affected by the stresses are interrelated

305 with respect to a measure of damage" (Higley et al., 1993). Because the incidence of stressors

306 (spittlebugs and stalk borers) was set experimentally, a stress response interaction, a

307 physiological change, must underlie our observed results.

Fundamentally, there are two possible explanations for our observed pattern of

photosynthetic activity and yield. First, if yield potential was set in February (early in sugarcane growth), then the combined treatment would have low yields, because the treatment had low

312 photosynthesis and final yield in all other treatments after February, which argues against vegetative growth not reproductive growth (which is where regulation of yield potential is most likely). Finally, sucrose accumulation in this system occurs between April and September, when the combined treatment had high photosynthetic rates, yet had low sucrose accumulation. with photosynthate accumulation or of a dramatic increase in costs of photosynthate

319 accumulation. Under normal conditions, photosynthetic rates are tightly regulated in association 
320 with sink demand, as moderated by environmental conditions (especially temperature and water

321 availability). It is difficult to see how photosynthesis would be uncoupled from photosynthate

322 production without producing down regulation of photosynthetic enzymes and(or), through the

323 production of peroxides, causing significant damage to thylakoid membranes leading to visible

324 symptoms like chlorosis (e.g., Macedo, 2003).

325 Because injury from both insects influences water use and availability, impaired water

326 relations is one potential mechanism by which photosynthesis and sugar accumulation might be

327 disrupted. Ordinarily, significant limitations in water availability are associated with reduced

328 stomatal conductance and (depending on the severity of the water stress) reduced photosynthesis.

329 We found no evidence of either effect (reduced stomatal conductance or reduced photosynthesis)

330 in measurements in April, June, or September; on the contrary, conductance and photosynthesis

331 were higher with combined injury, as compared to other treatments.

332 However, effects of injury on other aspects of sugarcane metabolism and water are

333 possible. Accumulation of sucrose requires movement against an osmotic gradient, consequently

334 there is an energy cost for this process. If injury of the combined insects impedes this process,

335 perhaps increased costs are required for sugar accumulation. Under such circumstances, there

336 would not necessarily be down regulation of photosynthesis despite reduced sugar mobilization

337 (through end product inhibition), because extra energy would be needed to maintain sugar

338 mobilization. Consequently, if injury by the combination of sugarcane borer + spittlebug leads to

339 increased costs for sugar accumulation, these costs might be indicated by higher respiration rates.

340 With our data, this explanation seems the most likely in accounting for the observed effects.

Beyond the interesting physiological issues raised by our examination of sugarcane

342 responses to multiple insect injuries, we see two other important outcomes from this study. First, 
343 our work illustrates that, as we originally hypothesized, sugarcane provides an excellent system

344 for examining the relationship between primary metabolism and yield (expressed as either

345 sucrose or total dry matter accumulation) unlike most other plant systems. Second, looking at

346 how individual and combined insect herbivores alter primary metabolism as well as yield

347 (however defined) can reveal relationships and interactions that are otherwise hidden.

\section{Acknowledgments}

The authors are grateful to São Martinho Sugar Mill for the technical support provided and Dr. Jessica Jurzenski for the English review of the first draft.

352

353

\section{References}

Anjos IA, Dinardo-Miranda LL, Garcia JC, Braz AJ, Tavares CB, Geromel RJ, Ferreira SS,

Souza VA, Duarte JCS. Spatial distribution of sugarcane spittlebug, Mahanarva fimbriolata, in sugarcane fields. In: International Society of Sugar Cane Technologists, 1., 2010, Vera CruzMexico. Proceedings... Vera Cruz: ISSCT, 2010. (CD-ROM)

Culy MD. 2001. Yield loss of field corn from insects. In: Peterson RKD, Higley LG, eds. Biotic stress and yield loss. Boca Raton: CRC Press, 43-71.

Dinardo-Miranda LL, Garcia V, Coelho AL. 2001. Eficiência de inseticidas no controle da 363 cigarrinha-das-raízes, Mahanarva fimbriolata, em cana-de-açúcar. STAB Açúcar, Álcool e Subprodutos 20:30-33. Agronômico. 
369 Dinardo-Miranda LL. 2008. Pragas. In: Dinardo-Miranda LL, Vasconcelos ACM, Landell MGA.

370 Cana-de-açúcar. Campinas: Instituto Agronômico, 349-404.

371

372 Fewkes DW. 1969. The biology of sugar cane froghoppers. In: Williams JR, Metcalf JR,

373 Mungomery RW, Mathes R. Pests of sugarcane. London: Elsevier Science, 283- 307.

374

375

376

Folin O, Ciocalteu V. 1927. On tyrosine and tryptophane determinations in proteins. The Journal of Biological Chemistry 73:627-650.

377

378

Gomez SK, Oosterhuis DM, Hendrix DL, Johnson DR, Steinkraus DC. 2006. Diurnal pattern of 379 aphid feeding and its effect on cotton leaf physiology. Environmental and Experimental Botany $380 \quad 55: 77-86$.

381

382

383

Guagliumi P. 1973. Pragas da cana-de-açúcar: Nordeste do Brasil. Rio de Janeiro: Coleção Canavieira.

384

385 386

Garcia JF, Botelho PSM, Parra JRP. 2006. Biology and fertility life table of Mahanarva fimbriolata (Stal) (Hemiptera: Cercopidae) in sugarcane. Scientia Agricola 63:317-320.

387

Garcia DB, Ravaneli GC, Madaleno LL, Mutton MA, Mutton MJR. 2010. Damages of spittlebug on sugarcane quality and fermentation process. Scientia Agrícola 67:555-561.

390

391

392

Garcia JF, Prado SS, Vendramim JD, Botelho SM. 2011. Effect of sugarcane varities on the development of Mahanarva fimbriolata (Hemiptera: Cercopidae). Revista Colombiana de 393 Entomología 37:16-20.

Haile FJ. 2001. The influence of cultivar and plant architecture on yield loss. In: Peterson RKD, 396 Higley LG. eds. Biotic stress and yield loss. Boca Raton: CRC Press, 99-116. 
398 Higley LG, Browde JA, Higley PM. 1993. Moving towards new understandings of biotic stress 399 and stress interactions. In: Buxton DR, Shibles R, Forsberg RA, Blad BL, Asay KH, Paylsen 400 GM, Wilson RF eds. International Crop Science I. Madison: CSSA, 749-754.

401

402 Ingram JW. 1946. Losses resulting from sugarcane borer injury to sugarcane in 1945. New 403 Orleans: Sugar Bulletin.

404

405

Landell MGA, Bressiani JA. 2008. Melhoramento genético, caracterização e manejo varietal. In: 406 Dinardo-Miranda LL, Vasconcelos ACM, Landell MGA. Cana-de-Açúcar. Campinas: Instituto 407 Agronômico, 101-155.

408

Long SP, Zhu X, Naidu SL, Ort DR. 2006. Can improvement in photosynthesis increase crop yields? Plant, Cell \& Environment. 29:315-330.

411

412

Macedo N, Botelho PSM. 1988. Controle integrado da broca da cana-de-açúcar Diatraea 413 saccharalis (Fabricius, 1794) (Lepidoptera, Pyralidae). Brasil Açucareiro 162:2-11.

Madaleno LL, Ravaneli GC, Presotti LE, Mutton MA, Fernandes OA, Mutton MJR. 2008. 417 juice. Neotropical Entomology 37:68-73.

Mendonça AF, Barbosa GVS, Marques EJ. 1996. As cigarrinhas da cana-de-açúcar no Brasil. In: Mendonça AF. Pragas da cana-de-açúcar. Maceió: Insetos \& Cia, 171-192.

Peterson RKD, Higley LG. 2001. Illuminating the black box: the relationship between injury and yield. In: Peterson RKD, Higley LG. eds. Biotic stress and yield loss. Boca Raton: CRC Press, 142412.

425 
430 Reddall A, Sadras VO, Wilson LJ, Gregg PC. 2004. Physiological responses of cotton to two431 spotted spider mite damage. Crop Science 44:835-846.

432

433 Schneider F. 1979. ICUMSA Methods of analysis. Cane Sugar Handbook. London: Pub. British 434 Sugar Corporation.

435

436 Stupiello JP. 2010. Intensidade de infestação e índice de danos. STAB Açúcar, Álcool e 437 Subprodutos 29:18.

438

439 Taiz L, Zeiger, E. 2006. Plant Physiology. Massachusetts: 4th, Sinauer Associates. Sunderland. 440

441 Tanimoto T. 1964. The press method of cane analysis. Aiea: Hawaiians Planter's Record, $442 \quad 57: 133-150$

443

444 Vaadia Y. 1985. The impact of plant stresses on crop yields. In: Key JL, Kosuge T, Liss AR.

445 Cellular and Molecular Biology of Plant Stress, New York, 71-92.

446

447

van Dillewijn C. 1952. Botany of sugarcane. Walthman: Chronica Botanica.

448

449 Welter SC. 1989. Arthropod impact and plant gas exchange. In: Bernays EA, Insect-Plant 450 interaction. Boca Raton: CRC Press, 135-150.

451

452 White WH, Viator RP, Dufrene EO, Dalley CD, Richard Junior EP, Tew TL. 2008. Re453 evaluation of sugarcane borer (Lepidoptera: Crambidae) bioeconomics in Louisiana. Crop 454 Protection 27:1256-1261. 


\section{Table $\mathbf{1}$ (on next page)}

Descriptive statistics (means and standard errors in parentheses), and ANOVA for biometric parameters at sugarcane harvest.

Includes stalk diameter, length, and wet weight (per ha); sucrose (per ha), phenolics (density per stalk), Brix (\%), starch concentration (per stalk), and brix (\%). Treatments included infestation by the sugarcane borer (Diatraea saccharalis) and spittlebug (Mahanarva fimbriolata), both pests, and a caged control. Letters after the mean (SE) indicate significant treatment differences by unprotected LSD. 
1 Table 1. Descriptive statistics (means and standard errors in parentheses), and ANOVA for biometric parameters at sugarcane

2 harvest, including: stalk diameter, length, and wet weight (per ha); sucrose (per ha), phenolics (density per stalk), Brix (\%), starch

3 concentration (per stalk), and brix (\%). Treatments included infestation by the sugarcane borer (Diatraea saccharalis) and spittlebug

4 (Mahanarva fimbriolata), both pests, and a caged control. Letters after the mean (SE) indicate significant treatment differences by

5 unprotected LSD.

6

\begin{tabular}{|c|c|c|c|c|c|c|c|}
\hline Treatment & $\begin{array}{c}\text { Stalk Diameter } \\
\text { (cm) }\end{array}$ & $\begin{array}{c}\text { Stalk Length } \\
\text { (cm) }\end{array}$ & $\begin{array}{c}\text { Stalk Fresh Weight } \\
\qquad\left(\text { t ha }^{-1}\right)\end{array}$ & $\begin{array}{l}\text { Sucrose } \\
\left(\mathbf{t ~ h a}^{-1}\right)\end{array}$ & $\begin{array}{l}\text { Phenolics } \\
\left(\mathrm{mg} \mathrm{dm}^{-3}\right)\end{array}$ & $\begin{array}{l}\text { Starch } \\
\left(\mathrm{mg} \mathrm{ml}^{-1}\right)\end{array}$ & $\begin{array}{l}\text { Brix } \\
\text { (\%) }\end{array}$ \\
\hline Control & $2.49(0.04) \mathrm{a}$ & $272.82(3.08) \mathrm{a}$ & $125.54(3.43) \mathrm{a}$ & $24.50(0.95) \mathrm{a}$ & $322.11(11.07) \mathrm{a}$ & $215.41(14.38) \mathrm{a}$ & $21.74(0.26) \mathrm{a}$ \\
\hline Borer & $2.43(0.01) \mathrm{ab}$ & $258.63(7.34) \mathrm{ab}$ & $116.85(4.73) \mathrm{ab}$ & $22.96(1.06) \mathrm{ab}$ & $348.42(38.62) \mathrm{a}$ & $130.78(37.21) \mathrm{a}$ & $21.93(0.18) \mathrm{a}$ \\
\hline Spittlebug & $2.32(0.04) \quad b$ & $245.44(9.58) \quad b$ & $103.41(5.00) \mathrm{b}$ & $20.79(1.15) b$ & $398.22(46.23) \mathrm{a}$ & $222.65(35.16) \mathrm{a}$ & $22.22(0.18) \mathrm{a}$ \\
\hline $\begin{array}{r}\text { Combination } \\
(\text { Borer }+ \text { Spittlebug })\end{array}$ & $2.36(0.02) \quad b$ & $248.47(3.18) \quad b$ & $\begin{array}{c}106.04(5.16) b \\
\text { ANOVA Treatme }\end{array}$ & $\begin{array}{l}20.42(0.86) b \\
\text { t Effects }\end{array}$ & $362.79(51.02) \mathrm{a}$ & $156.40(32.69) \mathrm{a}$ & $21.79(0.39) \mathrm{a}$ \\
\hline $\mathrm{F}_{3,9}$ & 4.46 & 3.31 & 5.70 & 4.67 & 1.06 & 2.03 & 1.12 \\
\hline $\operatorname{Pr}>F$ & 0.035 & 0.071 & 0.018 & 0.031 & 0.414 & 0.181 & 0.390 \\
\hline
\end{tabular}




\section{Table 2 (on next page)}

Regression statistics for regressions reported in Figures 3 and 4: yield (sucrose or stem weight) vs. apparent photosynthesis rates.

For all linear regressions df for $F$ is 1,3 except for mean seasonal photosynthesis which is 1 , 4. Non-linear regressions (Fig. 3B and 3C) are "Michaelis-Menten" equations of the form $Y=$ $V \max * X /(K m+X)$; goodness of fit was evaluated by $R^{2}$ and runs test (no significant deviation from model was found for any non-linear regression). 
2 Table 2. Regression statistics for regressions reported in Figures 3 and 4: yield (sucrose or stem weight) vs. apparent photosynthesis 3 rates. For all linear regressions df for $\mathrm{F}$ is 1,3 except for mean seasonal photosynthesis which is 1, 4. Non-linear regressions (Fig. 3B 4 and 3C) are "Michaelis-Menten" equations of the form $\mathrm{Y}=\mathrm{V}_{\max }{ }^{*} \mathrm{X} /\left(\mathrm{K}_{\mathrm{m}}+\mathrm{X}\right)$; goodness of fit was evaluated by $\mathrm{R}^{2}$ and runs test (no 5 significant deviation from model was found for any non-linear regression).

\begin{tabular}{|c|c|c|c|c|c|c|}
\hline Figure & Photosynthesis $(=\mathrm{X})$ & Yield (=Y) & Equation & $\mathbf{R}^{2}$ & $\mathbf{F}$ & $\mathbf{P}>\mathbf{F}$ \\
\hline $3 \mathrm{~A}$ & Mean Seasonal & $\begin{array}{l}\text { Sucrose } \\
\text { Stalk Weight }\end{array}$ & $\begin{array}{l}Y=2.573 * X+0.9656 \\
Y=13.16 * X+4.158\end{array}$ & $\begin{array}{l}0.9305 \\
0.9452\end{array}$ & $\begin{array}{l}53.52 \\
68.99\end{array}$ & $\begin{array}{l}0.0019 \\
0.0011\end{array}$ \\
\hline $3 \mathrm{~B}$ & Mean Seasonal with combined injury & $\begin{array}{l}\text { Sucrose } \\
\text { Stalk Weight }\end{array}$ & $\begin{array}{l}Y=26.84 * X /(1.613+X) \\
Y=160.20 * X /(13.49+X)\end{array}$ & $\begin{array}{l}0.9732 \\
0.9761\end{array}$ & & \\
\hline $3 \mathrm{C}$ & Mean Seasonal without combined injury & $\begin{array}{l}\text { Sucrose } \\
\text { Stalk Weight }\end{array}$ & $\begin{array}{l}\mathrm{Y}=47.95 * \mathrm{X} /(8.731+\mathrm{X}) \\
\mathrm{Y}=302.00 * \mathrm{X} /(12.89+\mathrm{X})\end{array}$ & $\begin{array}{l}0.9963 \\
0.9960\end{array}$ & & \\
\hline $4 \mathrm{~A}$ & February & $\begin{array}{l}\text { Sucrose } \\
\text { Stalk Weight }\end{array}$ & $\begin{array}{l}Y=0.4518^{*} X+14.17 \\
Y=2.558 * X+66.13\end{array}$ & $\begin{array}{l}0.9309 \\
0.8704\end{array}$ & $\begin{array}{l}26.95 \\
13.43\end{array}$ & $\begin{array}{l}0.0352 \\
0.0671\end{array}$ \\
\hline $4 \mathrm{~B}$ & April & $\begin{array}{l}\text { Sucrose } \\
\text { Stalk Weight }\end{array}$ & $\begin{array}{l}Y=0.4975 * X+18.29 \\
Y=3.062 * X+87.14\end{array}$ & $\begin{array}{l}0.3720 \\
0.4110\end{array}$ & $\begin{array}{l}1.185 \\
1.396\end{array}$ & $\begin{array}{l}\text { NS } \\
\text { NS }\end{array}$ \\
\hline $4 \mathrm{C}$ & June & $\begin{array}{l}\text { Sucrose } \\
\text { Stalk Weight }\end{array}$ & $\begin{array}{l}Y=2.111 * X+10.67 \\
Y=11.84 * X+46.93\end{array}$ & $\begin{array}{l}0.8750 \\
0.8029\end{array}$ & $\begin{array}{l}13.99 \\
8.147\end{array}$ & $\begin{array}{r}0.0646 \\
0.104\end{array}$ \\
\hline $4 \mathrm{D}$ & September & $\begin{array}{l}\text { Sucrose } \\
\text { Stalk Weight }\end{array}$ & $\begin{array}{l}\mathrm{Y}=1.804 * \mathrm{X}+6.710 \\
\mathrm{Y}=11.32 * \mathrm{X}+13.92\end{array}$ & $\begin{array}{l}0.7400 \\
0.8499\end{array}$ & $\begin{array}{l}5.691 \\
11.32\end{array}$ & $\begin{array}{c}\text { NS } \\
0.0781\end{array}$ \\
\hline
\end{tabular}




\section{Figure 1 (on next page)}

Photosynthetic rates of sugarcane plants infested by sugarcane borer, spittlebug, and combined pests.

Means followed by different letters, capital letters comparing seasons and small letters comparing treatments, were significantly different by LSD Test $(P \leq 0.05)$. 


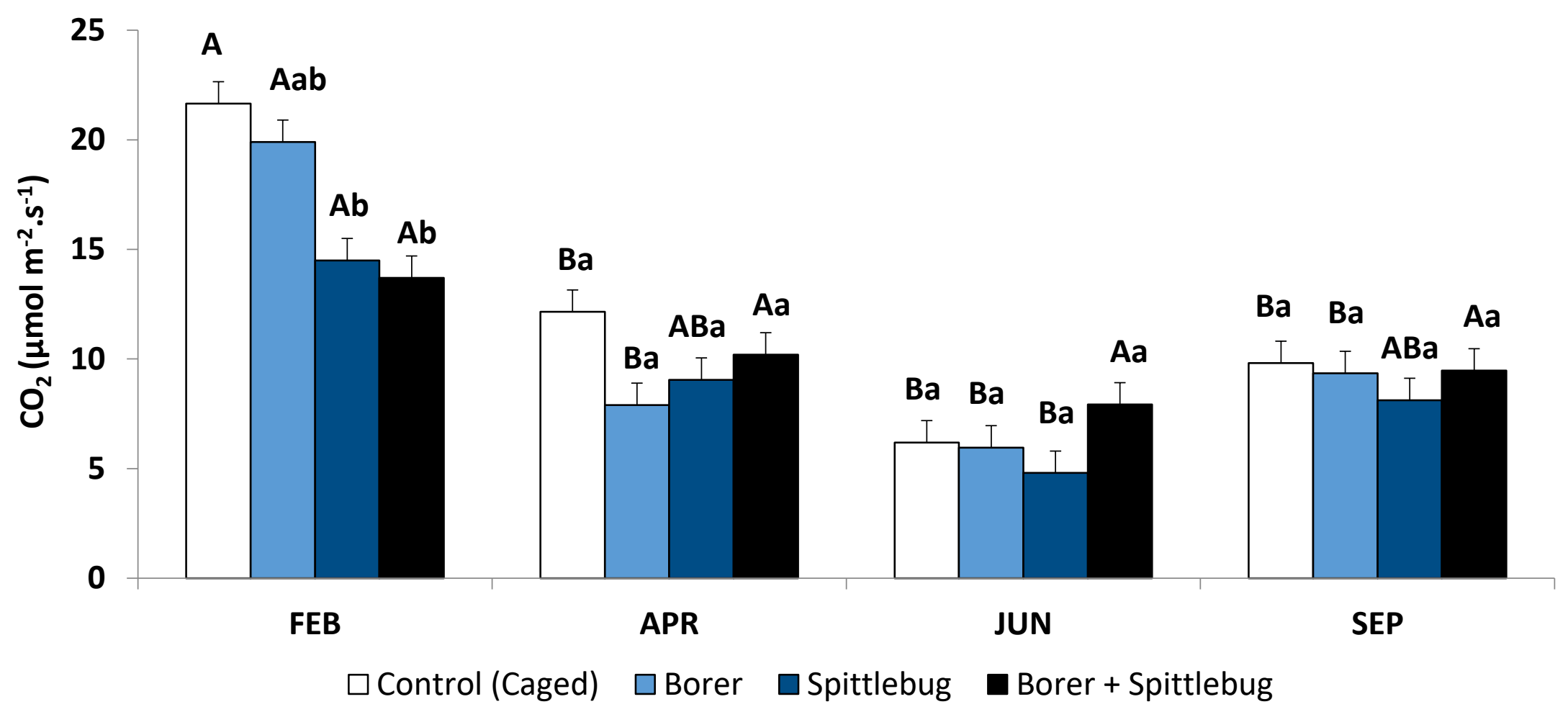




\section{Figure 2 (on next page)}

Monthly accumulated rainfall precipitation and mean temperature and net radiation measured in the experimental area. 


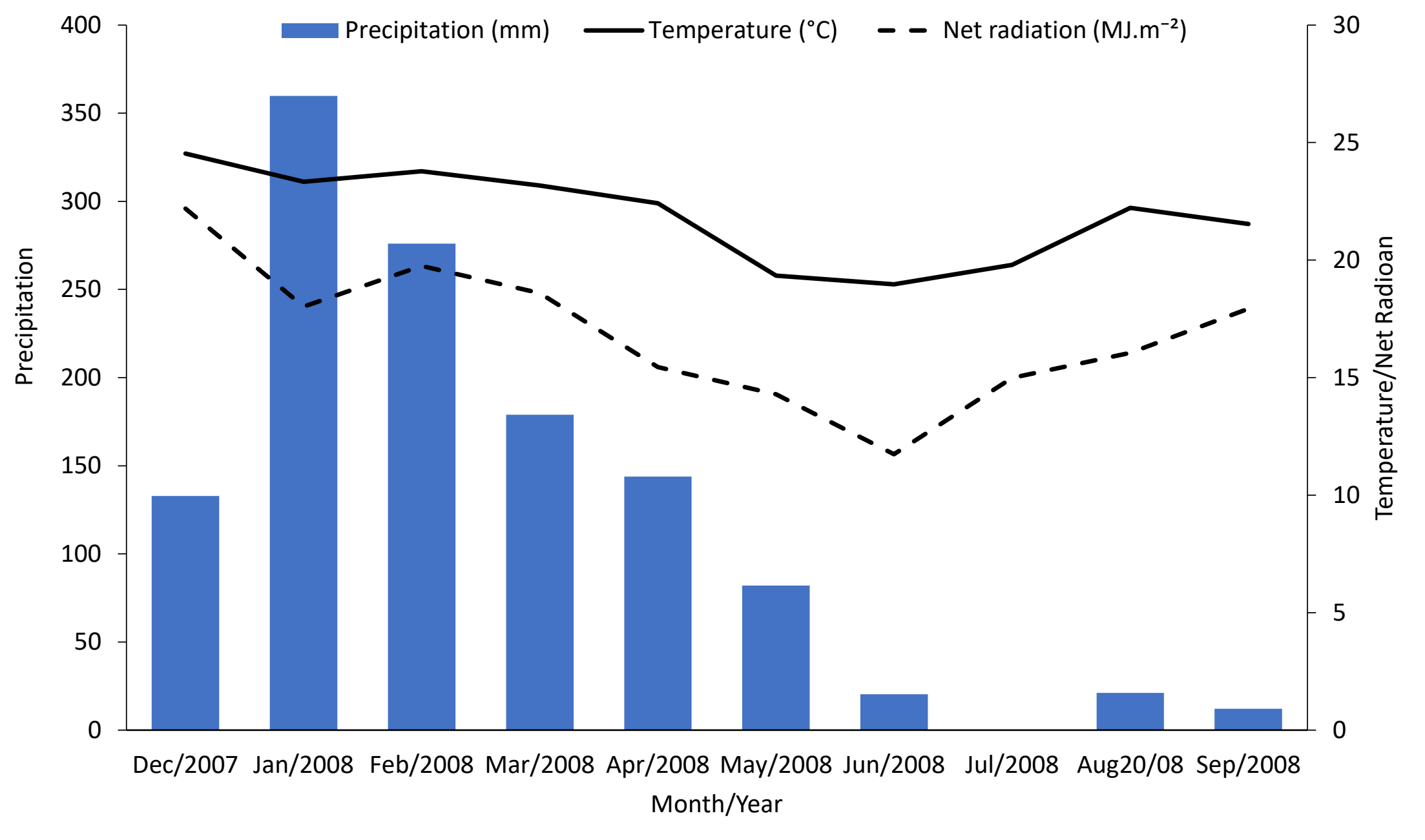




\section{Figure 3 (on next page)}

Regression relationships between seasonal mean photosynthesis and final sucrose yield and stalk weight. Dotted lines indicate $95 \%$ confidence intervals for the regressions.

Figure $3 \mathrm{~A}$ shows the linear regression of yield versus seasonal mean photosynthesis and includes all data points. Figure 3B shows the non-linear $(Y=V \max * X /(K m+X))$ fit with all data points (points for combined injury are circled in black). Figure $3 C$ shows the non-linear $Y$ $=V m a x * X /(K m+X))$ fit excluding points for combined injury. Regression statistics are listed in Table 2. 
A Yld vs Seasonal Mean Photosynthesis Linear Regression

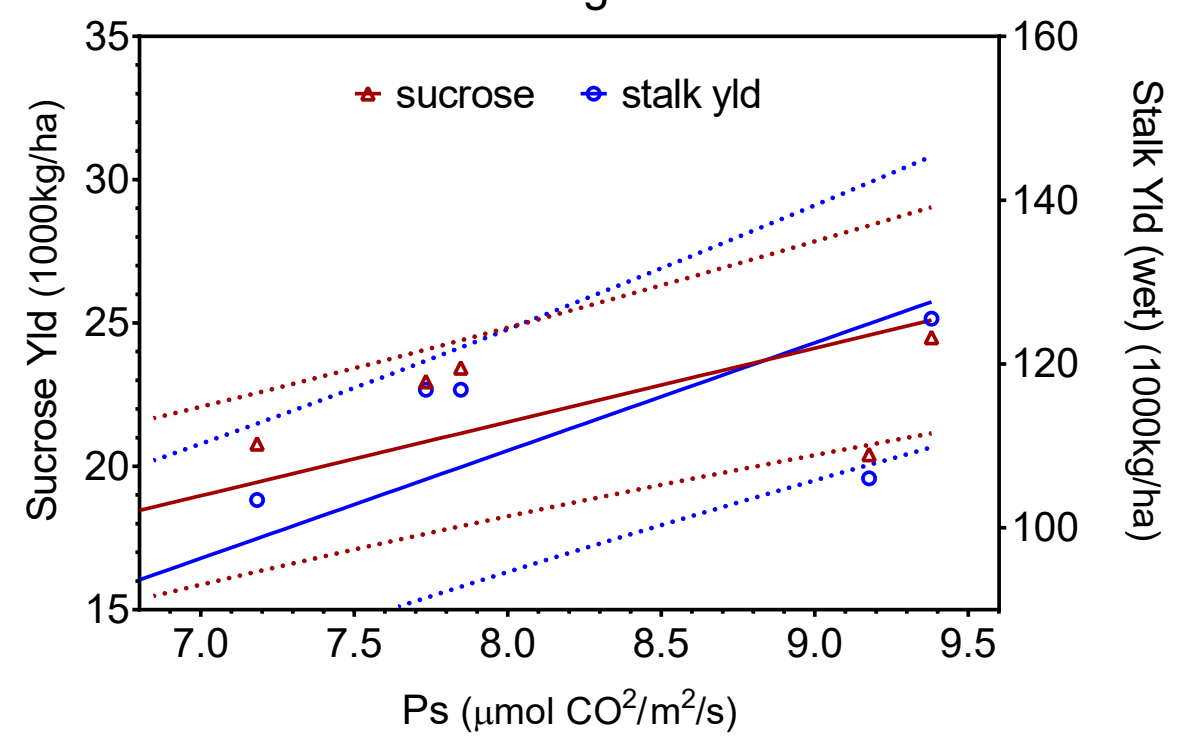

B Yld vs Seasonal Mean Photosynthesis With All Treatments by Nonlinear Regression

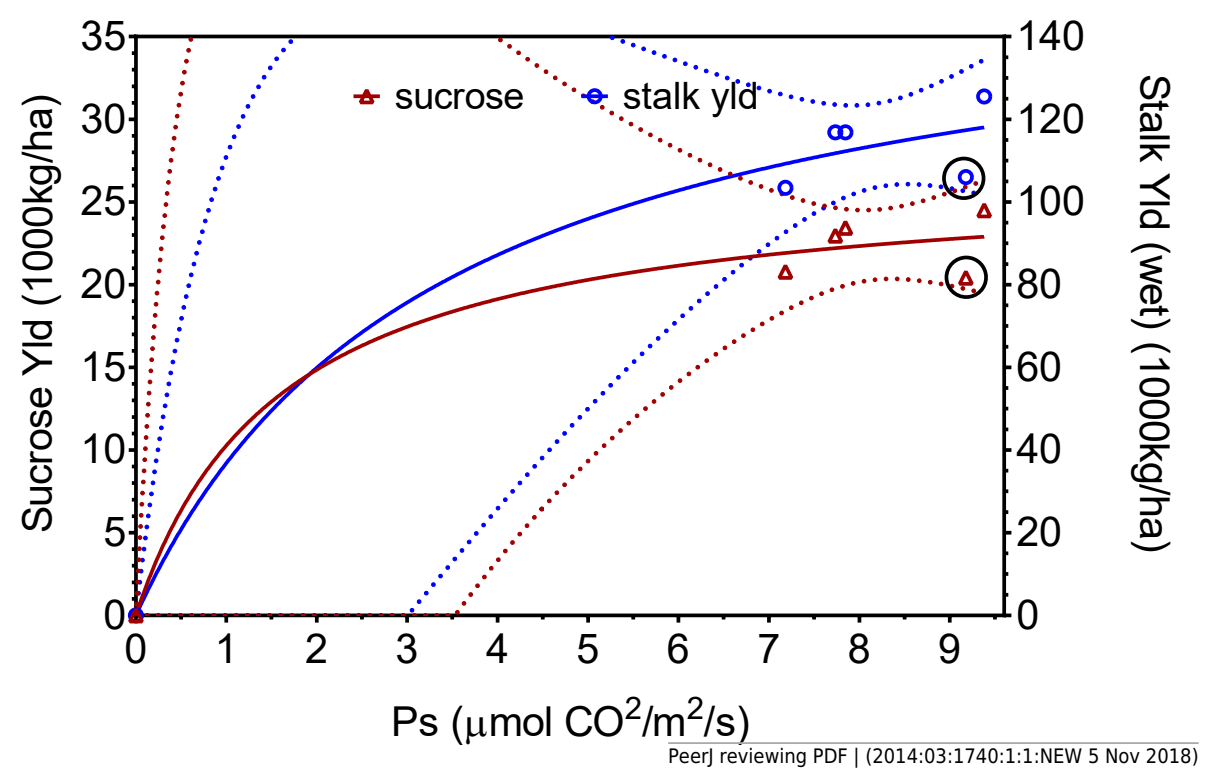

C Without Stalk Borer + Spittlebug Treatment

by Nonlinear Regression

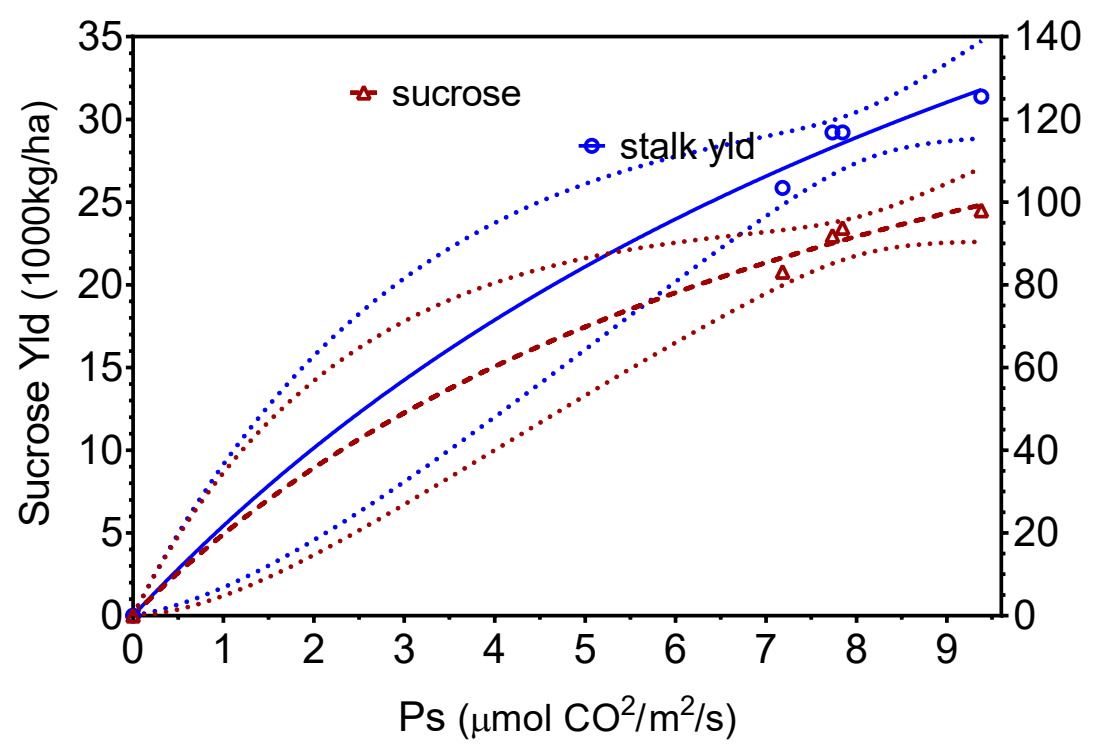


Figure 4(on next page)

Linear regression relationships between photosynthesis and final sucrose yield and stalk weight by month (4A February, 4B April, 4C June, and 4D September). Dotted lines indicate $95 \%$ confidence intervals for the regressions.

Regressions include all points except the combined (sugarcane borer+ spittlebug) treatments. Regression statistics are listed in Table 2. 


\section{A Yld vs Februrary Photosynthesis}

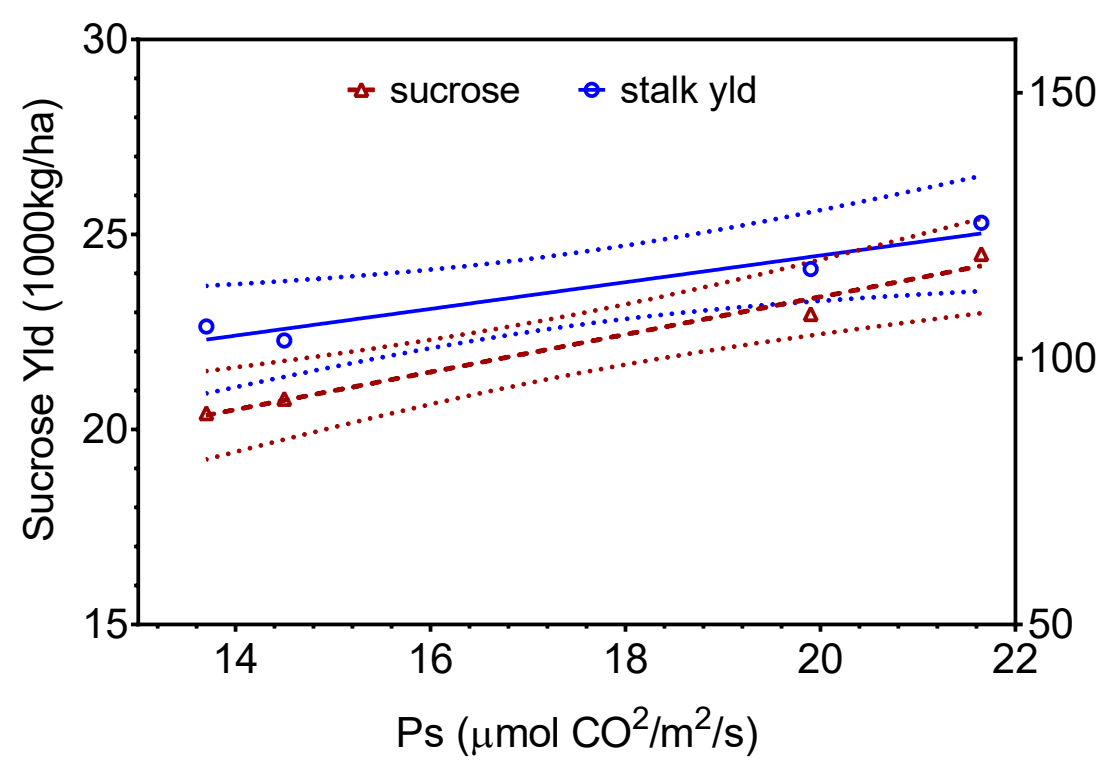

C

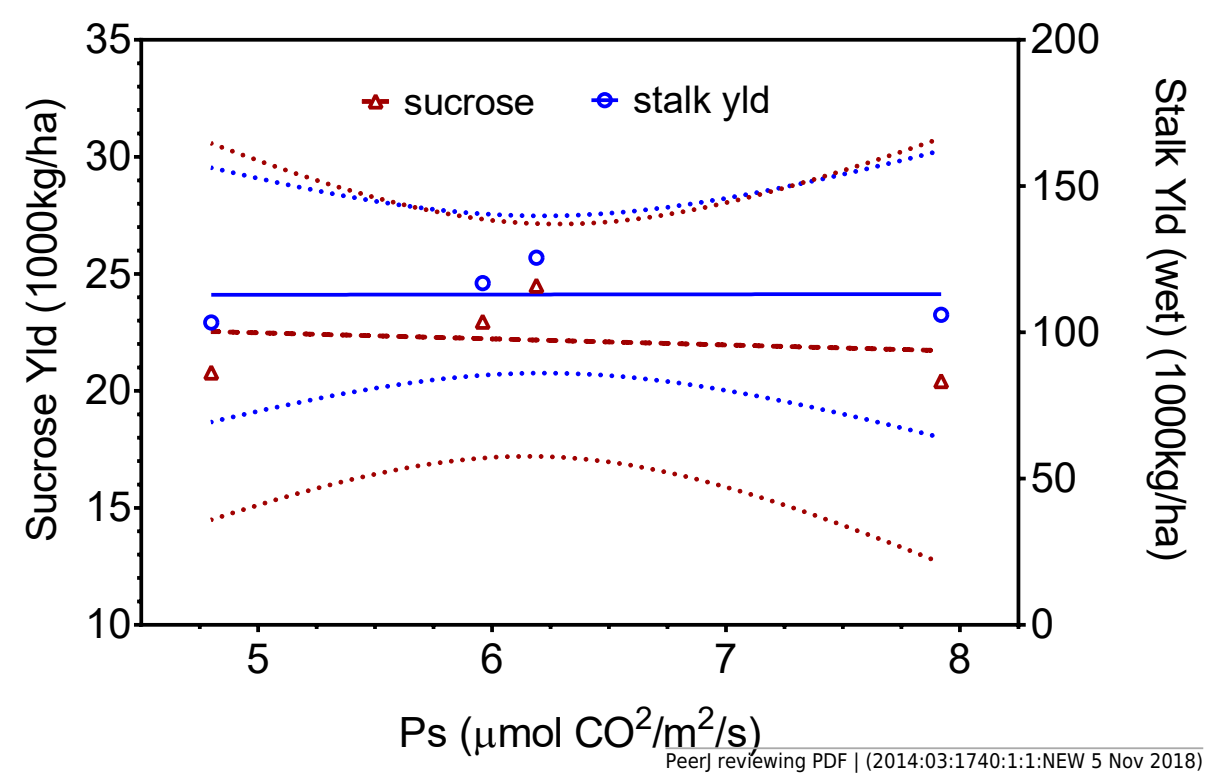

B Manuscript to be reviewed

Yld vs April Photosynthesis

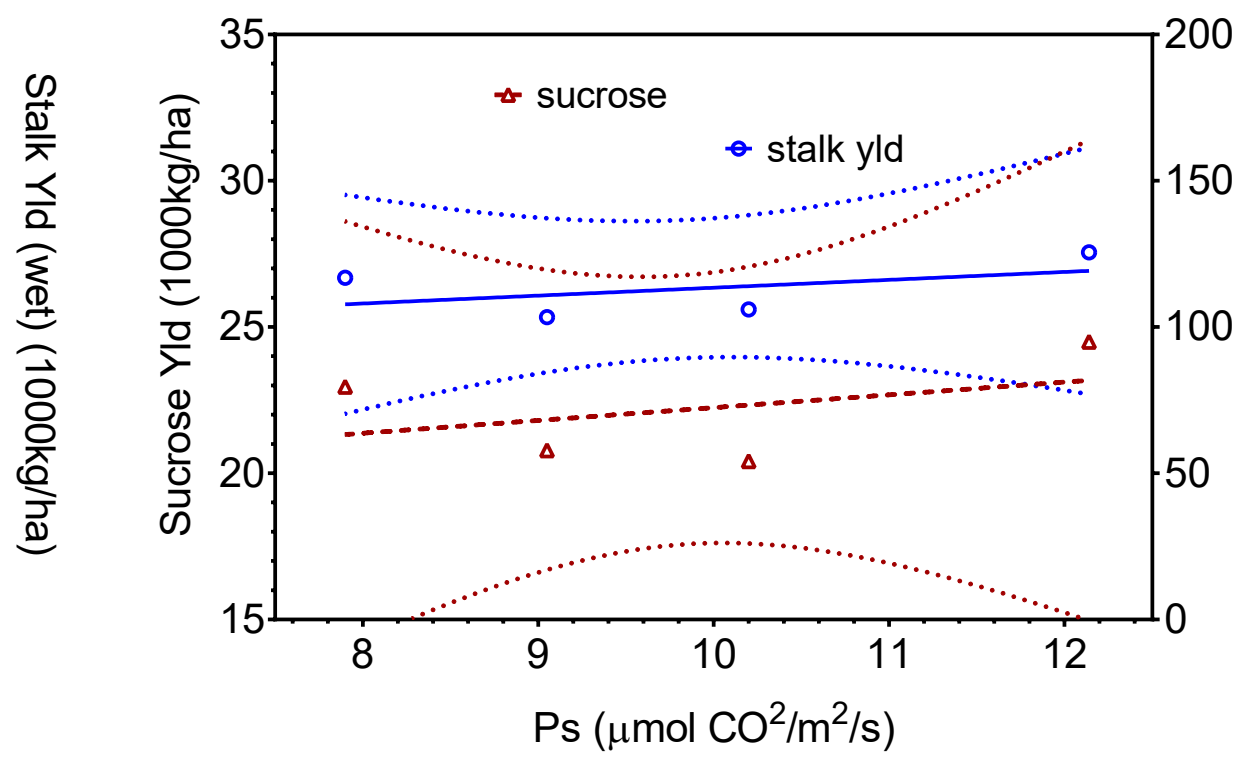

D

Yld vs September Photosynthesis

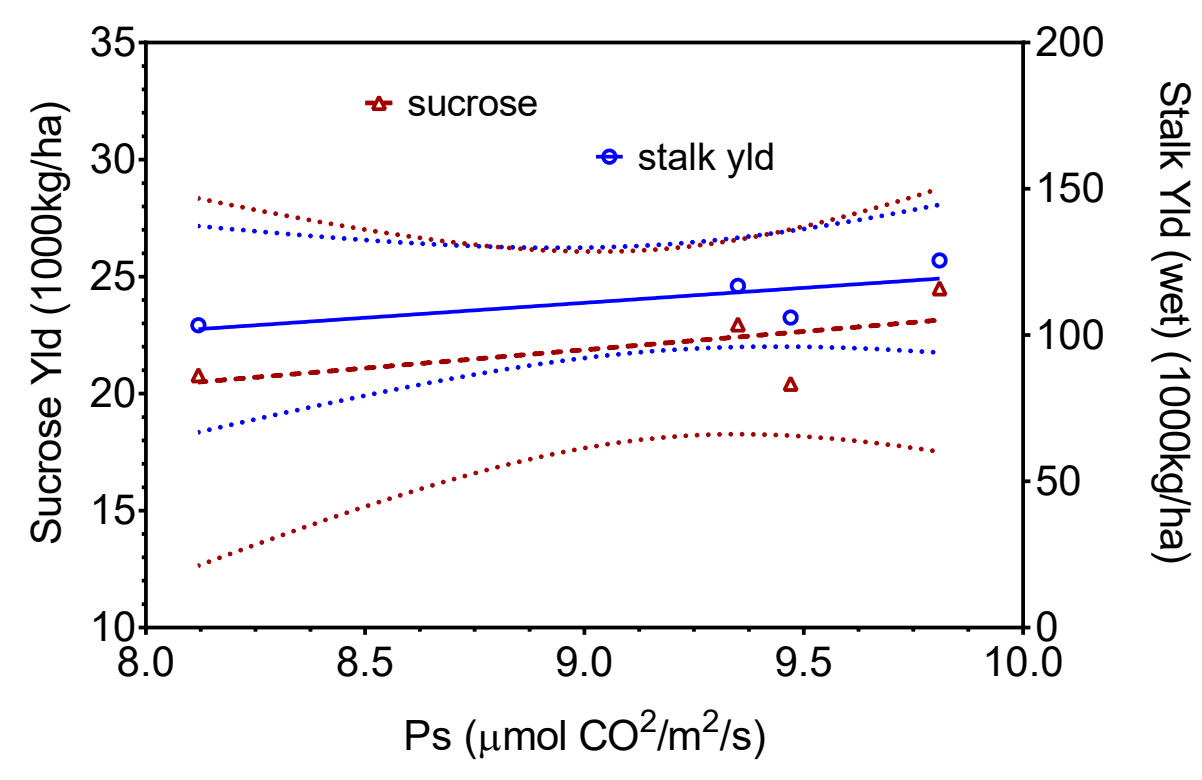

